\title{
PETROGRAPHIC ANALYSIS OF THE VOLCANIC BOMBS AND BLOCKS FROM POÁS VOLCANO: APRIL-JUNE 2017 ERUPTIVE PERIOD
}

\author{
ANÁLISIS PETROGRÁFICO DE LAS BOMBAS Y BLOQUES VOLCÁNICOS DEL \\ VOLCÁN POÁS: \\ PERIODO ERUPTIVO DE ABRIL A JUNIO DE 2017
}

\author{
Pilar Madrigal* y Oscar H. Lücke
}

\section{Escuela Centroamericana de Geología, Universidad de Costa Rica, Costa Rica, P.O. Box 214-2060, San Pedro, Costa Rica \\ Centro de Investigaciones Geológicas, Universidad de Costa Rica, Costa Rica *Autora para contacto: mariadelpilar.madrigal@ucr.ac.cr}

(Recibido: 24/06/2017; aceptado: 23/08/2017)

\begin{abstract}
During the first semester of 2017, Poás Volcano, in the Central American Volcanic Arc (CAVA) initiated a period of volcanic unrest that included high energy phreatomagmatic and magmatic eruptions. The most notable eruptions occurred on April 14 ${ }^{\text {th }}$ and April $22^{\text {nd }}$ of 2017, which produced abundant ashes and ballistic materials in the form of blocks and bombs. Here, we present results from the petrographic analyses conducted in the collected material from the largest eruptions of April 2017. Mineral textures observed on the petrographic analyses show evidence of reactivation and fragmentation of a crystal mush in the magma chamber, triggering re-melting episodes, volatile exsolution, and an increase in the pressure of the system, all of which are expected conditions during an eruption episode. Our analyses done on juvenile and non-juvenile material suggest that processes of magma mingling and injections of new batches of material of different compositions have played an important role throughout previous eruptions and likely in the current phase of volcanic activity in Poás.
\end{abstract}

Keywords: Poás, volcanic activity, magmatic processes, igneous petrography, crystallization.

Resumen: Durante el primer semestre del 2017, el volcán Poás situado en el arco volcánico centroamericano (AVCA) inició un periodo de actividad volcánica que incluyó erupciones freatomagmáticas y magmáticas. Las erupciones más destacadas ocurrieron los días 14 y 22 de abril del año 2017. Estas erupciones produjeron la dispersión de ceniza y abundantes materiales balísticos en la forma de bloques y bombas. En este trabajo, presentamos los resultados de los análisis petrográficos realizados en los productos eruptivos de Poás para el mes de abril de 2017. Las texturas minerales observadas a partir del análisis petrográfico muestran la evidencia de la reactivación y fragmentación de un agregado cristalino en la cámara magmática y el disparo de episodios de fusión, exsolución de volátiles y un incremento en la presión del sistema. Todas estas condiciones son de esperar en un proceso eruptivo. Los análisis realizados en material 
juvenil y no juvenil sugieren que los procesos de mezcla de magmas e inyección de volúmenes nuevos de material con distinta composición han tenido una influencia importante en procesos eruptivos anteriores y en la nueva fase de actividad volcánica en Poás.

Palabras clave: Poás, actividad volcánica, procesos magmáticos, petrografía ígnea, cristalización.

\section{INTRODUCTION}

Poás volcano is a complex stratovolcano that rises 2708 m.a.s.l. within the northern section of the Central Cordillera of Costa Rica, and constitutes one of the most active volcanoes in the Central American Volcanic Arc (CAVA). It is characterized by gentle slopes and a wide summit caldera, where the main crater lies, along with the Botos and Von Frantzius cones. All the identified volcanic foci associated with the massif are aligned with N-S volcano-tectonic fracture zones.

The last significant eruptive episodes are those of 1910 and 1953. According to (Casertano, Borgia, \& Cigolini, 1983) both of these episodes were phreatomagmatic where the 1910 eruption dispersed fine juvenile material in a single episode whereas the 1953 eruptions lasted several months with strombolian type activity, the creation of an intra-crateric dome by effusion of lava and the disappearance of the crater lake for a period of close to a decade. Phreato-magmatic eruptions, according to (Browne \& Lawless, 2001), involve the ejection of juvenile igneous material thus directly involving magma as a source of ejecta.

Since the early 1950's, the activity of Poás volcano has been limited to phreatic events in which ash, mud, lapilli and blocks has been dispersed, mainly within the borders of the active crater's caldera. According to (Barberi, Bertagnini, Landi, \& Principe, 1992), phreatic eruptions are processes of fragmentation of pre-existing rock and ash due to explosions of steam. These eruptions do not directly involve magma as a source of material. In phreatic eruptions, magma acts as the source of energy by heating and flashing water from a shallow aquifer (Browne \& Lawless, 2001; Rouwet et al., 2014).
During the first semester of 2017 Poás volcano initiated a period of volcanic unrest characterized by vigorous eruptions (ejecting bombs and blocks), ash spewing episodes, and nearly constant degassing. This current episode is accompanied by persistent seismic activity, which entails mainly low-frequency tremors and volcanotectonic earthquakes (Mora, 2017a). Furthermore, the hyper acidic crater lake has disappeared and an asymmetric cinder cone or tuff ring has formed in the southern edge of the active crater (Fig. 1).

Its proximity to densely populated areas and the popularity of Poás Volcano as one of the most visited national parks in Costa Rica justifies the importance of monitoring the current activity and studying the magmatic products of the current eruption of Poás volcano. This work aims to assess the petrographic characteristics of the blocks and bombs ejected during the recent eruptions of Poás Volcano in order to infer crystallization and fragmentation processes involving the underlying magmatic system.

\section{ACTIVITY RECORDED IN THE FIRST SEMESTER OF 2017}

During the period of January to April of 2017 Poás Volcano presented a significant increase in seismological activity which at the end of March, resulted in persistent volcanic tremors, low frequency events, and volcano-tectonic earthquakes (Mora, 2017a). On April 13 ${ }^{\text {th }}$, a small phreatic eruption dispersed sediments from the crater's lake around the area inside the main active caldera.

From April $12^{\text {th }}$ to $14^{\text {th }}$ the eruptive sequence initiated with an eruption that eroded the central section of the inner dome and fractured 


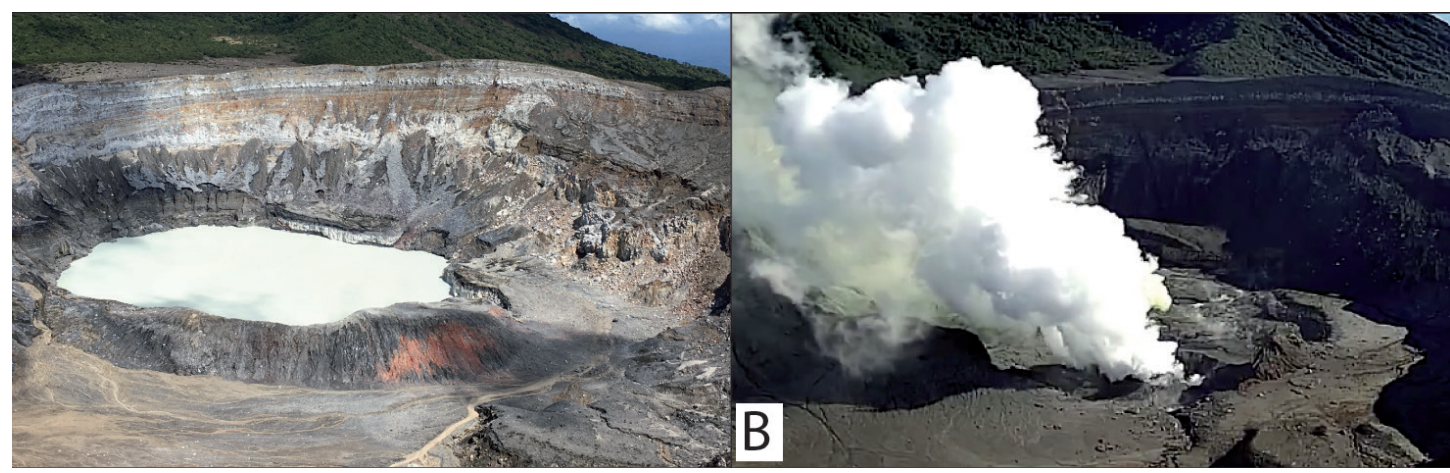

Fig. 1. Caldera containing the active crater of Poás Volcano. A: Structure of the 1953 lava dome located on the southern edge of the crater as seen in February of 2017. B: Structure of the southern edge of the active crater as seen on August 22 ${ }^{\text {nd }}, 2017$, note the absence of the dome structure. Image from the National Seismological Network's (RSN) camera, courtesy of Mauricio Mora.

the structure through its SE wall. According to (Mora, 2017a) the eruption was accompanied by a 40 minute long tremor at frequencies near 2.0 Hz. On April $13^{\text {th }}$ two intense eruptions occurred within the hyperacid lake which ejected blocks and sediments that reached a minimum radius of $2 \mathrm{~km}$ surrounding the active crater. The fragments erupted belonged mainly to non-juvenile material from the affected dome.

The eruptive activity continued until April $14^{\text {th }}$ when two more episodes occurred. During these events, a gas and ash column formed, reaching heights of up to $3 \mathrm{~km}$ and new ejecta covered the main crater, including blocks $(10 \mathrm{~cm}$ up to $1 \mathrm{~m}$ in diameter) and sediments (Mora, 2017b; OVSICORI, 2017). However, this material was still dominated by non-juvenile components. Fifteen more small-scale eruptions occurred during the twenty-four hour interval following the main event. These small-scale eruptions showed phreatic to phreatomagmatic characteristics.

After the April $12^{\text {th }}-14^{\text {th }}$ activity the dome disappeared due to the continuous eruptions and only a remnant structure of the southeastern edge of the former dome remains visible. In addition, the main crater's lake started to dry significantly allowing the fumarole degassing to occur directly to the atmosphere. Some of these vents displayed Sulphur-rich gas and water vapor fumaroles that presented a yellow hue.

On April 22 nd, vigorous activity resumed, with ash and gas eruptions during which a new pyroclastic cone or tuff ring formed. This new feature rose $15 \mathrm{~m}$ above the bottom of the crater's edge with an aperture of $80 \mathrm{~m}$ approximately (OVSICORI, 2017). The external wall appeared to be formed by reddish scoria fragments.

Toward the end of the first semester of 2017, volcanic unrest continued in the form of intense degassing with occasional dispersion of ash and incandescent ballistic fragments. The last significant eruption during this period occurred on June $11^{\text {th }}$, with a concentrated ash plume dispersed toward the SSE.

\section{METHODS}

The collection of block and bomb samples took place at the southern edge of the active crater's caldera, around the tourist lookout of the national park where the ballistic impacts left craters of several decimeters in diameter (Fig. 2A). Ash samples were collected on the vicinity of the lookout from the solar panels of the RSN seismological station VPS6 (Fig. 2B) and from the roof of the visitors' center.

Thin sections prepared for the bomb and block samples were observed on a polarizing microscope (Nikon Eclipse LV100N POL) and photographed for image stacking using the software Combine ZP (www.hadleyweb.pwp.blueyonder. co.uk). Ash samples were sifted and submitted to ultrasonic baths using distilled water. Preferably, 


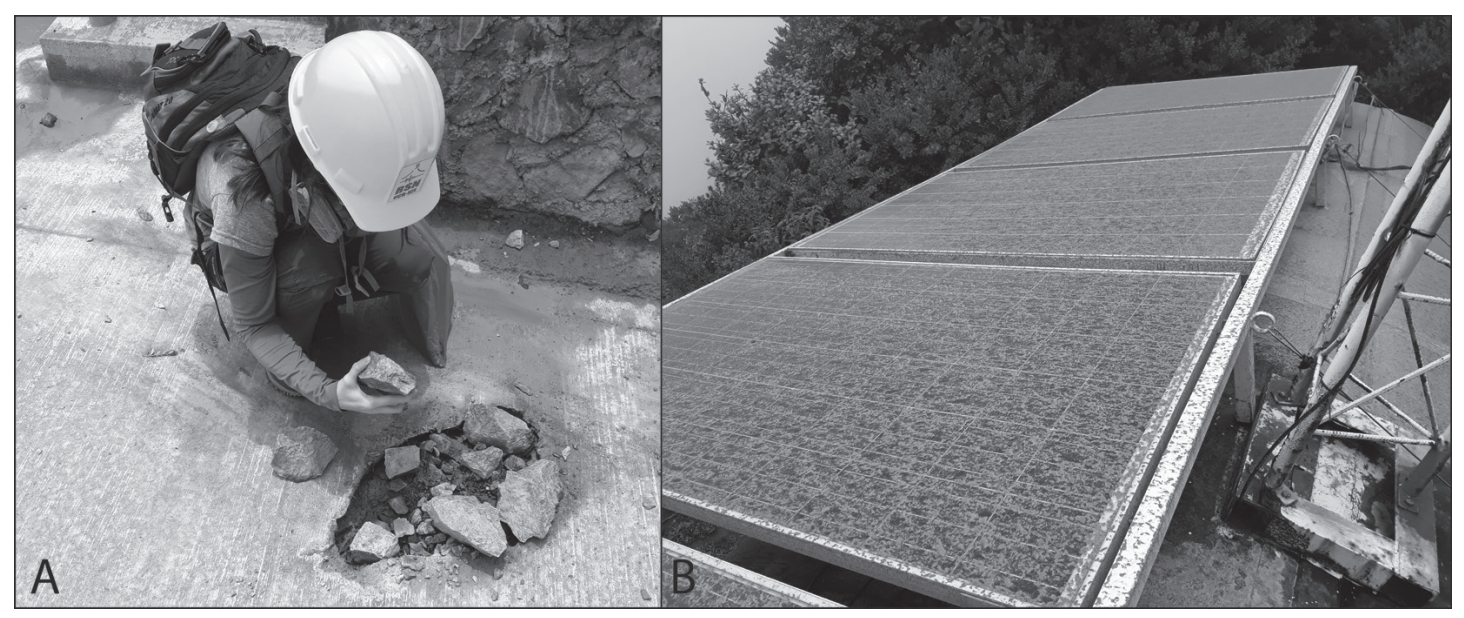

Fig. 2: A: collection of block samples from the April $12^{\text {th }}$ to $14^{\text {th }}$ eruptions, note the crater pierced on the solid concrete by the block's impact. B: Ash covered solar panels of the seismological station VPS6 of the RSN, photos taken on April $15^{\text {th }}, 2017$.

the fractions from $2.7 \phi$ to $2 \phi(0.15$ to $0.25 \mathrm{~mm})$ were observed under non-polarized light on a stereo microscope (Nikon SMZ1270).

\section{RESULTS}

\section{Blocks}

On April 14 $4^{\text {th }}, 2017$ and subsequent episodes, Poás volcano dispersed large blocks that left significant impact craters around the upper caldera as shown in figure 2. These blocks may have been part of the lava dome formed in 1953 on the southern end of the active crater and bordered the intracrateric lake. From this date forward, the dome appeared severely eroded with only the eastern part protruding from the crater's edge as a remnant.

Overall, the blocks show a hypocrystalline, porphyritic texture with plagioclase, clinopyroxene, orthopyroxene, and olivine phenocrysts in an intersertal matrix (Figs. 3A and 3B).
Clinopyroxene phenocrysts $(6 \%)$ appear unaltered (Figs. 3C and 3D). Olivine phenocrysts (2\%) appear opacitized and show kelyphitic rims composed of orthopyroxene (Figs. 3C and 3D). Orthopyroxene as phenocrysts are scarce $(<1 \%)$. Plagioclase phenocrysts (29\%) show a poorly developed sieved texture and zoning, some are arranged as radiated laths showing incipient variolitic texture (Figs. 3E and 3F). Opaque minerals account for $2 \%$ of the phenocrysts. The intersertal matrix $(60 \%)$ is composed mainly of plagioclase (35\%) with interstitial tan colored (CMYK: 0,14 , $26,18)$ glass $(21 \%)$, opaque minerals $(3 \%)$ and clinopyroxene $(<1 \%)$.

\section{Bombs}

The bombs have a hypocrystalline, porphyritic, highly vesicular $(50 \%)$ texture with plagioclase, clinopyroxene, orthopyroxene, and olivine phenocrysts in an intersertal matrix (Figs. 4A and 4B). Plagioclase phenocrysts $(20 \%)$ show clearly defined sieved textures in the center of 


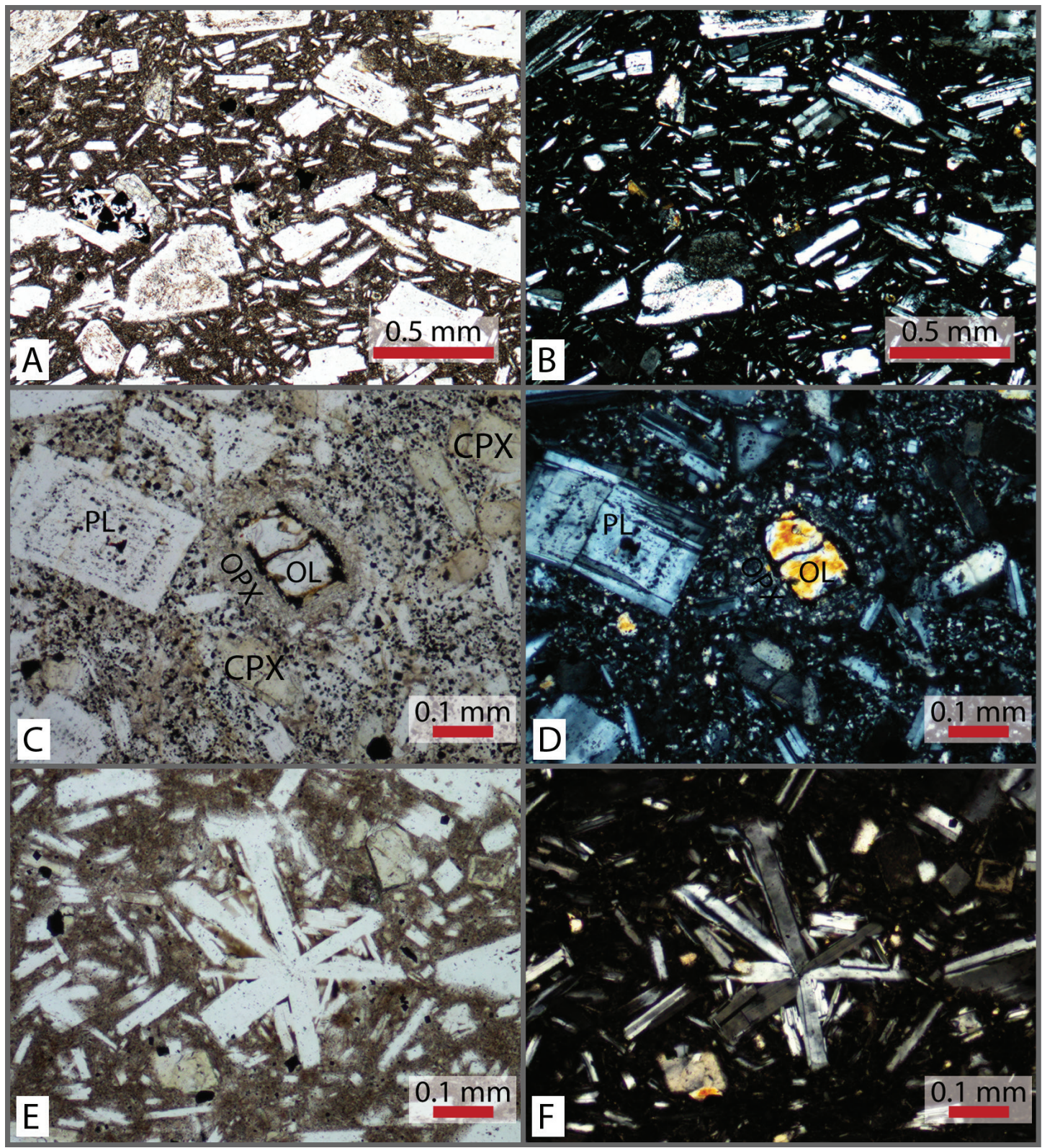

Fig. 3: Thin section of a block erupted by Poás volcano on April 14 $4^{\text {th }}, 2017$ under polarized (A, C, E) and cross-polarized (B, D, F) light. A/B: Overview of hypocrystalline porphyritic texture. C/D: Opacitized olivine (OL) phenocryst with orthopyroxene (OPX) kelyphitic rim. E/F: Radiated plagioclase laths showing incipient variolitic texture. 


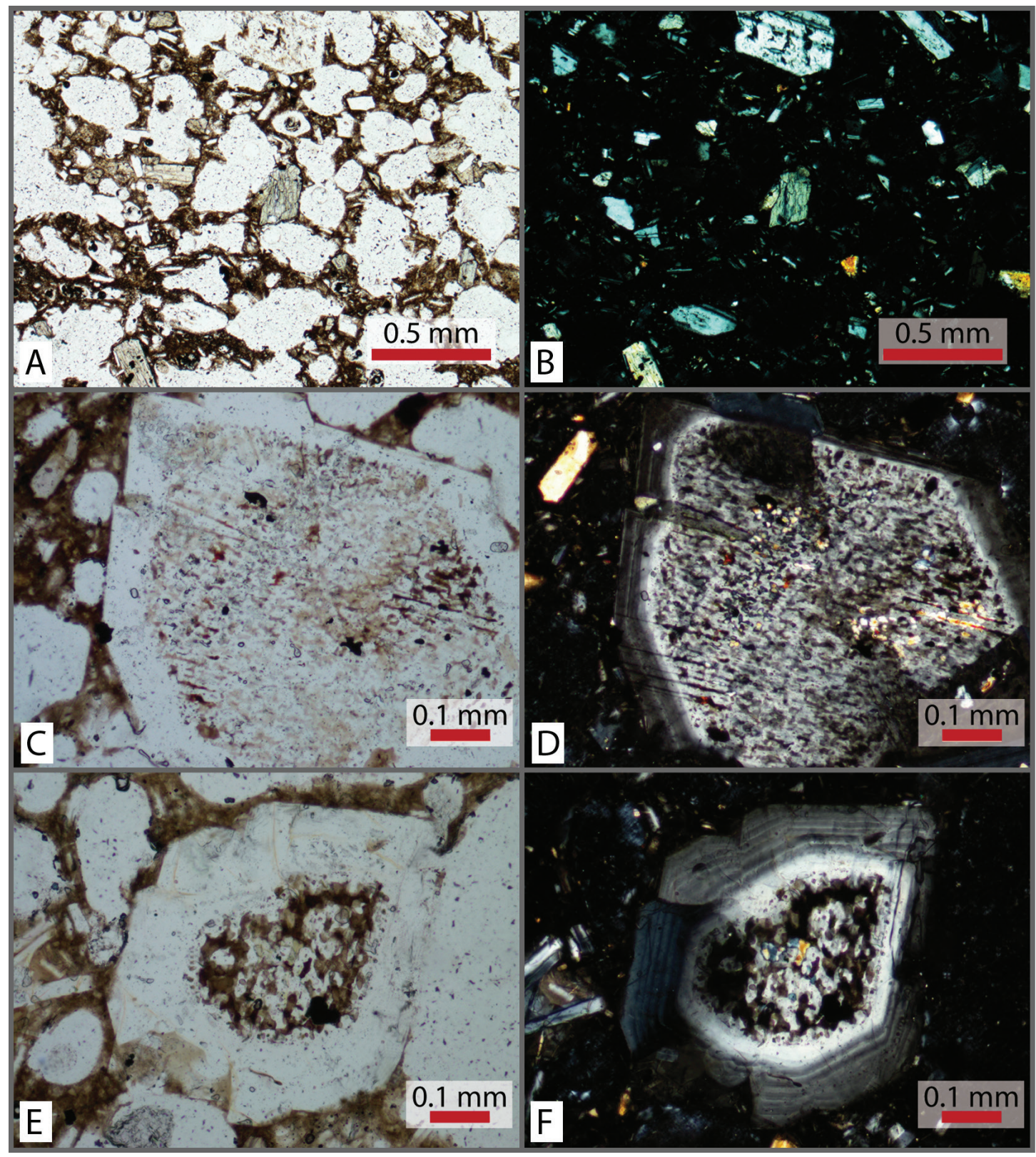

Fig. 4: Thin section of a bomb erupted by Poás volcano on April of 2017 under polarized (A, C, E) and cross-polarized (B, D, F) light. A/B: overview showing vesicular, hypocrystalline porphyritic texture. C/D: Plagioclase phenocryst with an inner core showing poikilitic texture with clinopyroxene inclusions as well as sieve texture with glass-filled interstices. The outer rim of the phenocryst lacks these features and shows strong, discontinuous zoning. E/F: Plagioclase phenocryst showing similar textures as figure $4 \mathrm{C}$ and $4 \mathrm{D}$ and a thicker, more developed zoned rim.

the crystals and a rim of strong discontinuous zoning (Figs. 4C, 4D, 4E, 4F). Most of the spaces on the sieved texture are occupied by glass (Figs.
4C and 4E) and larger phenocrysts show a poikilitic texture with clinopyroxene inclusions (Figs. $4 \mathrm{D}$ and $4 \mathrm{~F})$. Clinopyroxene phenocrysts $(6 \%)$ are 


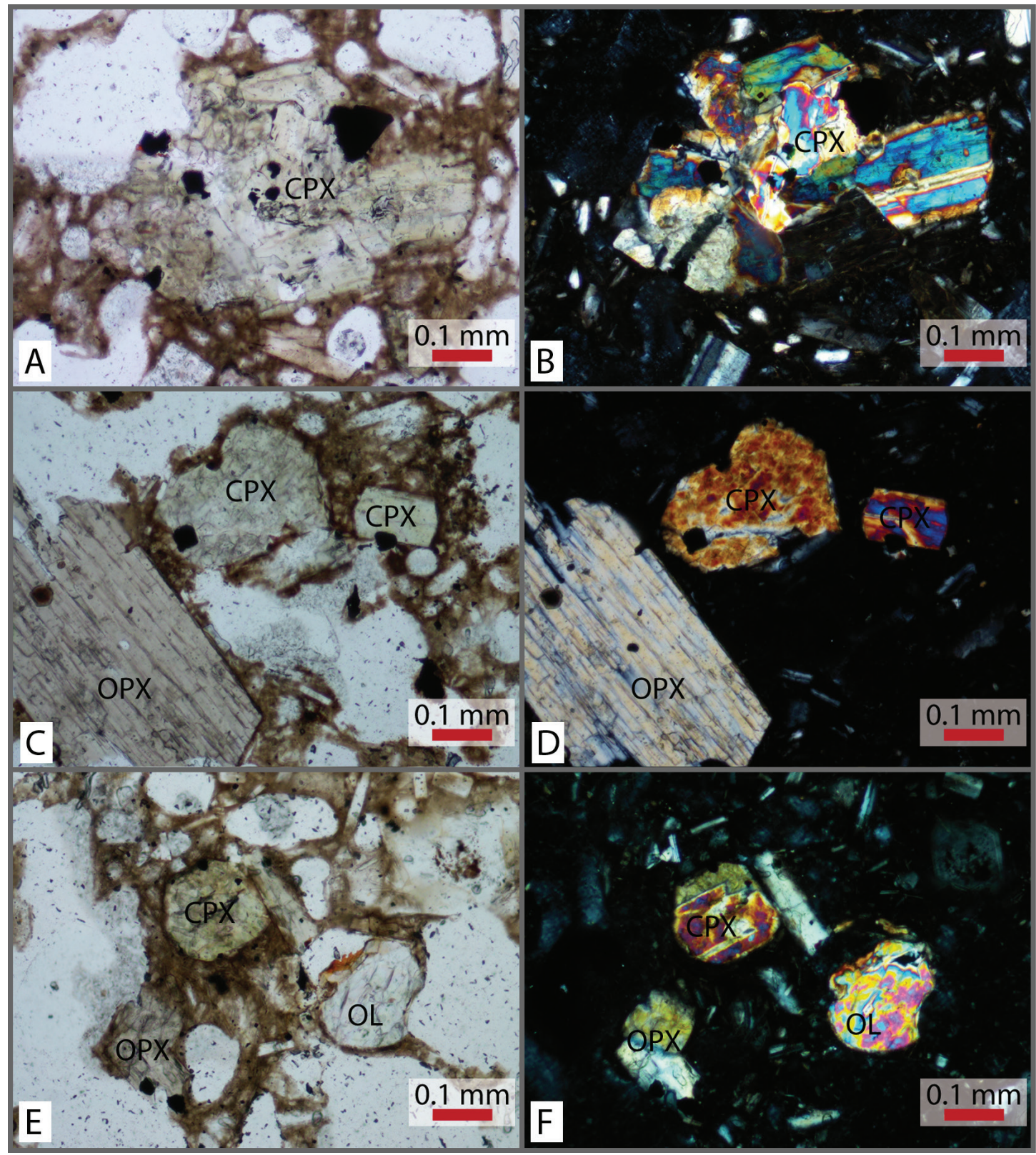

Fig. 5: Thin section of a bomb erupted by Poás volcano on April of 2017 under polarized (A, C, E) and cross-polarized (B, D, F) light. A/B: overview showing vesicular, hypocrystalline porphyritic texture. C/D: Plagioclase phenocryst with an inner core showing poikilitic texture with clinopyroxene inclusions as well as sieve texture with glass-filled interstices. The outer rim of the phenocryst lacks these features and shows strong, discontinuous zoning. E/F: Plagioclase phenocryst showing similar textures as figure 4C and 4D and a thicker, more developed zoned rim.

arranged as cumulates in a glomeroporphyritic texture (Figs. 5A and 5B) although some appear as individual euhedral phenocrysts (Figs. 5C and
5D). Orthopyroxenes (3\%) appear as euhedral phenocrysts (Figs. 5C and 5D) and unlike the orthopyroxene present in the blocks, they do not 
form kelyphitic rims. Olivine phenocrysts (Figs. $5 \mathrm{E}$ and $5 \mathrm{~F}$ ) account for $1 \%$ of the phenocrysts. The intersertal matrix (20\%) is composed of plagioclase $(11 \%)$ with interstitial reddish brown (CMYK: $6,32,63,14)$ glass $(7 \%)$, opaque minerals $(1 \%)$ and clinopyroxene $(<1 \%)$.

\section{DISCUSSION}

\section{Blocks}

The block collected on April of 2017 constitutes a fragment of an andesitic lava that most likely belonged to the disappeared dome (Fig. 1). The alignment of feldspar microlites in the matrix indicates a flow vector during the rock's cooling history (Fig. 3A). Plagioclase is a dominant mineral phase in the sample; it shows a poorly developed sieved texture in some of the crystals, zoning, or both in some cases (Figs. 3C and 3D). Both textures are indicative of magmatic differentiation occurring during formation of the dome in the 1953 eruptive phase. A similar differentiation process may be taking place in the current period of activity.

The presence of glomeroporphyritic texture composed by plagioclase aggregates (Figs. 3E and $3 \mathrm{~F}$ ) suggests heterogeneous nucleation of plagioclase in preexisting phenocrysts within the magma chamber. Additionally, at the time of formation, the magma maintained an ascent velocity that surpassed that of the sedimentation velocity rate of the aggregates (Lange, Nielsen, Tepley, \& Kent, 2013). Since the density of the glomerocrysts is greater than that of individual plagioclase crystals, it may play an important role in the fractionation process of plagioclase within a magma chamber or intrusion (Hogan, 1993).

Olivine doesn't seem to be a mineral phase from the magma that formed the rock, since it is not an abundant mineral in the sample, but, most importantly, it shows evidence of chemical disequilibrium with the surrounding matrix (Figs. 3C and 3D). The presence of oxidation at the crystal rims, and the formation of a reaction halo of orthopyroxene around the phenocrysts suggest that olivine might be a xenocryst that is not in equilibrium with the melt that carried it to the surface.

Centimetric to metric andesitic lava blocks were ejected during the eruption of April 22 $2^{\text {nd }}$ 2017, nevertheless, most of them corresponded to non-juvenile material. We infer that this sample belonged to the eroded dome which disappeared after the April 2017 eruptions.

\section{Bombs}

The textures and zonations in phenocrysts are indicative of processes within the magma chamber and conduits of a volcanic system. In an open system such as a magma chamber with an active recharge, processes like degassing, crystallization, magma mixing and mingling, and assimilation of country rock can happen simultaneously, leaving a trace in the phenocrysts' textures and morphology (Streck, 2008).

Most porphyritic lavas may contain evidence of some degree of magma mixing. As a magma reservoir gets replenished by new melts, crystals in the crystal-mush will suffer changes due to the geochemical disequilibrium that entails a new batch of material ascending from the mantle wedge (in the case of a subduction zone).

From the samples collected after the April $22^{\text {nd }}$ eruptions, the bomb shows characteristics common to juvenile ejecta. It is very vesicular and the matrix is intersertal with feldspar microlites, mainly plagioclase (Fig. 4A and 4B). Most of the phenocrysts in this vesicular lava are plagioclase crystals that show cores with a strong sieved texture that gradually disappears towards the rims. Furthermore, the plagioclase phenocrysts' rims show a fine zoning pattern, surrounding the sieved core (Fig. 4C-F).

The sieved texture at the core of the crystals can develop during the residence time of the mineral in a magma chamber. Changes in composition during magma recharge or even temperature changes during reservoir mixing. Resorption in plagioclase could result in dissolution surfaces and could happen due to rapid growth. Decompression can produce pervasive resorption as well (Pearce \& Kolisnik, 1990). 
Additionally, it is worth noting that many of the plagioclase phenocrysts become zoned towards the crystal edges, showing very thin transition fringes. Nevertheless, in most cases, these phenocrysts maintain the sieved texture of the core. This may imply recharge processes within the magma chamber, where initially the phenocrysts crystallized under relatively undisturbed conditions that allowed the core to undergo resorption and probably rapid growth. Afterwards, a new batch of melt was introduced into the reservoir, changing the compositional equilibrium and triggering convective currents, resulting in a highly dynamic environment (Couch, Sparks, \& Carroll, 2001). Under such conditions, preexisting phenocrysts tend to re-equilibrate by crystalizing successive rims of different composition around their lattice, thus forming the zoned edges. The convective currents are likely to be a consequence of new injections of material that cause magmatic fractionation and ultimately changes the composition of the surrounding liquid, hence, modifying the composition of the plagioclase crystal lattices creating successive changes of the anorthite content of the plagioclase fringes.

The presence of clino- and ortho-pyroxene cumulates suggests that a process of crystallization/solidification was already active previous to the disequilibrium produced by new magmatic injections responsible for the current episode of unrest. These cumulates represent transported fragments of the crystal mush that was already forming in the magma chamber. The ascent of a new magma batch fragmented the cooling crystal mush carrying the pyroxene cumulates along the flux. Since the crystal mush is already in a near-solid state, the separation of cumulates occurs by brittle breaking of the crystals, which is evident also in the minerals observed in the ashes from the eruption in April and May, where many of the minerals show normal and concoidal microfractures (Huber, Bachmann, \& Dufek, 2011; Karlstrom, Rudolph, \& Manga, 2012).

Few olivine crystals can be identified in the thin section and they show oxidized rounded borders and alteration to iddingsite, suggesting that they may be xenocrysts instead of phenocrysts from the new batch of magma. The incorporation of preexisting xenocrysts is not an uncommon phenomenon, where the ascension of fresh magma can erode the surrounding conduit walls including crystals from previous magmatic episodes. Nevertheless, this interpretation should be confirmed by performing geochemical analyses to demonstrate if the olivine is in compositional equilibrium with the surrounding melt.

\section{CONCLUSIONS}

The material ejected from the recent eruptions of Poás Volcano contains petrographic and morphological evidence that suggests that the current period of unrest is related to the entrainment of new material into the magma chamber below. The influx of new batches of magma with a different composition can change the equilibrium of a given magma chamber triggering processes of magma mixing and mingling, which are related to convective currents.

Mechanical mixing resulting from convective currents could affect the stability of a previously stablished crystal mush near the lower sections of Poás' magma chamber. The reactivation and fragmentation of this crystal mush can trigger re-melting episodes, volatile exsolution, and an increase in the pressure of the whole system, all of which are expected conditions during an eruption episode (Parmigiani, Huber, \& Bachmann, 2014). Crystal resorption observed in the bombs collected from the recent eruptions, as well as the brittle deformation and concoidal fractures found in the mineral crystals from the analyzed ashes may be an evidence for reactivation of the crystal mush due to magmatic recharge. Additionally, signs of active magmatic recharge are not only observed in the ejected products but are also evident in the increased volcanic and volcano-tectonic seismicity measured by the local seismic network.

Continued monitoring is necessary to determine if the recharge process develops further. More eruptions can be expected during the current activity episode at Poás depending on the extent of the magma mixing and mingling, as well as in the bulk composition of the new magma batches ascending from the 
source. We recommend to perform additional geochemical analyses from the juvenile ash fragments (primarily glasses and minerals) of the recent eruptions to ascertain the compositions of mixing endmembers and to achieve a better understanding of the processes associated to the compositional disequilibrium of the Poás magma chamber.

\section{ACKNOWLEDGEMENTS}

The authors acknowledge the contribution of L.F. Brenes, J.P. Calvo, and G.J. Soto in the collection of samples for this study and Dr. Mauricio Mora and Dr. Javier Pacheco for their contribution with real-time monitoring of seismological activity which allows us to safely perform field work near Poás' active crater. This article is a contribution to research project 113B5-A00 entitled: "Geofísica y geodinámica interna del arco volcánico en Costa Rica”, from the University of Costa Rica.

\section{REFERENCES}

Barberi, F., Bertagnini, A., Landi, P. and Principe, C. (1992). A review on phreatic eruptions and their precursors. Journal of Volcanology and Geothermal Research, 52(1992), 231-246. doi:10.1016/03770273(92)90046-g

Browne, P. R. L. and Lawless, J. V. (2001). Characteristics of hydrothermal eruptions, with examples from New Zealand and elsewhere. Earth-Science Reviews, 52(4), 299-331. doi:10.1016/s00128252(00)00030-1
Casertano, L., Borgia, A. and Cigolini, C. (1983). El volcán Poás, Costa Rica: cronología y características de la actividad. Geofisica Internacional, 22(3), 215-233.

Couch, S., Sparks, R. and Carroll, M. (2001). Mineral disequilibrium in lavas explained by convective self-mixing in open magma chambers. Nature, 411(6841), 1037-1039.

Hogan, J. P. (1993). Monomineralic Glomerocrysts: Textural Evidence for Mineral Resorption during Crystallization of Igneous Rocks. The Journal of Geology, 101(4), 531-540. doi:10.1086/648245

Huber, C., Bachmann, O. and Dufek, J. (2011). Thermo-mechanical reactivation of locked crystal mushes: Melting-induced internal fracturing and assimilation processes in magmas. Earth and Planetary Science Letters, 304(3), 443-454. doi: dx.doi. org/10.1016/j.epsl.2011.02.022

Karlstrom, L., Rudolph, M. L. and Manga, M. (2012). Caldera size modulated by the yield stress within a crystal-rich magma reservoir. Nature Geoscience, 5(6), 402.

Lange, A. E., Nielsen, R. L., Tepley, F. J., \& Kent, A. J. R. (2013). The petrogenesis of plagioclase-phyric basalts at mid-ocean ridges. Geochemistry, Geophysics, Geosystems, 14(8), 3282-3296. doi:10.1002/ggge.20207

Mora, M. (2017a). Resumen de la actividad sísmica y eruptiva del Volcán Poás 13 de abril de 2017. San José: Red Sismológica Nacional, Universidad de Costa Rica. Informe interno. 
Mora, M. (2017b). Resumen de la actividad sísmica y eruptiva del Volcán Poás 12 al 14 de abril de 2017. San José: Observatorio Vulcanológico y Sismológico de Costa Rica, Universidad Nacional. Informe interno.

OVSICORI. (2017). Desaparición de Lago y Otros Cambios Radicales en el Fondo del Volcán Poás (Reporte de campo: 07 de junio de 2017). San José: Observatorio Vulcanológico y Sismológico de Costa Rica, Universidad Nacional. Informe interno.

Parmigiani, A., Huber, C. and Bachmann, O. (2014). Mushmicrophysics and the reactivation of crystal-rich magma reservoirs. Journal of Geophysical Research, 119, 6308-6322. doi:10.1002/2014JB011124
Pearce, T. and Kolisnik, A. (1990). Observations of plagioclase zoning using interference imaging. Earth-Science Reviews, 29(1-4), 9-26.

Rouwet, D., Sandri, L., Marzocchi, W., Gottsmann, J., Selva, J., Tonini, R. and Papale, P. (2014). Recognizing and tracking volcanic hazards related to non-magmatic unrest: a review. Journal of Applied Volcanology, 3(17), 1-17. doi:10.1186/ s13617-014-0017-3

Streck, M. J. (2008). Mineral Textures and Zoning as Evidence for Open System Processes. Reviews in Mineralogy and Geochemistry, 69(1), 595-622. doi:10.2138/rmg.2008.69.15 
